\title{
Blood Groups and Enzymes of Human Red Cells after Five Years' Storage in Liquid Nitrogen
}

\author{
R. G. HUNTSMAN, * M.D., M.R.C.P., M.C.PATH.; B. A. L. HURN, $\dagger$ M.D., M.C.PATH. \\ ELIZABETH W. IKIN, PH.D.; H. LEHMANN,§ M.D., SC.D., F.R.C.P., F.R.I.C., F.C.PATH. \\ J. LIDDELL, $\|$ M.D., M.C.PATH.
}

Brit. med. 9., 1967, 4, 458-460

Laboratories interested in blood group serology need to preserve a reference panel of red cells of known antigenic structure. For the sake of continuous availability, especially of the rarer types, it is often desirable that the cells should be stored for long periods of time at sub-zero temperatures, a state which can be achieved without gross lysis only by the use of special techniques. For some years past we have been evaluating the quality of preservation of human red cells stored in liquid nitrogen $\left(-196^{\circ} \mathrm{C}\right.$.) after rapid freezing of droplets of a wholeblood/sucrose mixture; the present paper records the behaviour of a panel of such cells, selected on account of their diverse grouping properties, and tested after storage for five years.

The methods employed were as previously reported (Huntsman, et al., 1962).

\section{Results}

Recovery of Intact Cells.-The average recovery in seven samples was $89.4 \%$ (range $87-94 \%$ ); changes in the average recovery over the five-year period are shown in Table I.

Antigen Strength.-The blood groups of the panel of cells are listed in Table II, and the titration scores of these cells after varying periods of storage are shown in Table III. The results on fresh samples from four of the original donors, tested in parallel with the five-year stored samples, are also included in Table III.

TABLE I - Average Recovery of Intact Cells When Thawed After Storage for Various Periods of Time

\begin{tabular}{l|c|c|c|c|c|c}
\hline $\begin{array}{l}\text { Storage } \\
\text { Recovery }\end{array}$ & $\begin{array}{l}1 \text { hour } \\
91.3^{*}\end{array}$ & $\begin{array}{l}1 \text { month } \\
\mathbf{9 2 . 5} \%^{*}\end{array}$ & $\begin{array}{c}1 \text { year } \\
\mathbf{9 4 . 1} \%\end{array}$ & $\begin{array}{c}2 \text { years } \\
\mathbf{9 2 . 8 \%}\end{array}$ & $\begin{array}{c}3 \text { years } \\
\mathbf{9 1 . 8 \%}\end{array}$ & $\begin{array}{c}5 \text { years } \\
\mathbf{8 9 . 4 \%}\end{array}$ \\
\hline
\end{tabular}

- Thawed in isotonic saline. Remaining specimens thawed in $1 \%$ saline.

TABLE II.-Blood Groups of the Seven Chosen Blood Samples

\begin{tabular}{|c|c|c|c|c|c|c|c|c|c|c|}
\hline $\begin{array}{c}\text { Speci- } \\
\text { men }\end{array}$ & $\mathrm{ABO}$ & $\mathbf{R h}$ & MN & $\mathbf{s}$ & $\mathbf{P}_{1}$ & $\mathbf{L u}$ & $\mathbf{K}$ & $\mathrm{Le}^{\mathrm{s}}$ & $L e^{b}$ & $\mathrm{Fy}^{\circ}$ \\
\hline $\begin{array}{l}1 \\
2 \\
3 \\
4 \\
5\end{array}$ & $\begin{array}{l}\mathrm{O} \\
\mathrm{O} \\
\mathrm{A}_{1} \\
\mathrm{O} \\
\mathrm{O}\end{array}$ & 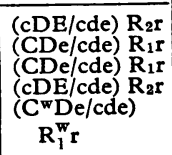 & $\begin{array}{l}M N \\
M \\
N \\
M \\
M\end{array}$ & $\begin{array}{l}\bar{t} \\
\bar{t} \\
+\end{array}$ & $\begin{array}{c}++t \\
= \\
++t \\
+++\end{array}$ & $\begin{array}{l}\bar{I} \\
\pm\end{array}$ & $\begin{array}{l}\bar{z} \\
\bar{t}\end{array}$ & $\begin{array}{l}- \\
\overline{-} \\
\pm \\
+\end{array}$ & $\begin{array}{l} \pm \\
+ \\
\pm \\
\pm\end{array}$ & $\begin{array}{l}\overline{+} \\
\pm \\
+\end{array}$ \\
\hline $\begin{array}{l}6 \\
7\end{array}$ & $\begin{array}{l}\mathbf{0} \\
\mathbf{0}\end{array}$ & $\begin{array}{l}\left(\mathrm{c} D^{\mathrm{u}} \mathrm{E} / \mathrm{cde}\right) \mathrm{R}_{2}^{\sigma} \mathrm{r} \\
(\mathrm{cde} / \mathrm{cde}) \mathrm{rr}\end{array}$ & $\begin{array}{l}M N \\
\text { N }\end{array}$ & \pm & + & - & $\overline{-}$ & - & $\begin{array}{l}+ \\
+\end{array}$ & $\begin{array}{l}+ \\
-\end{array}$ \\
\hline
\end{tabular}

Enzymes.-Table IV compares the activities of aldolase, aspartate aminotransferase (glutamic oxalacetic transaminase), glucose 6-phosphate dehydrogenase, and 6-phosphogluconate dehydrogenase in four of the five-year stored samples with those found in fresh cells taken from the same donors.

- Consultant Haematologist, Lambeth and St. Thomas's Hospitals, London S.E.1.

† Clinical Pathologist, Wellcome Research Laboratories, Beckenham, Kent.

\# Senior Scientific Officer, Medical Research Council Blood Group

Reference Laboratory, London N.W.3.

Reference Laboratory, London N. University of Cambridge.

1 Professor of Chemical Pathologist, Guy's Hospital, London S.E.1.

\section{Discussion}

Strumia et al. (1960) reported a 90\% recovery of red cells after storage for two years at $-93^{\circ} \mathrm{C}$. and Doebbler et al. (1965) found no significant change in red cell recovery rates after two and a half years at $-170^{\circ} \mathrm{C}$. The recovery of high proportion of intact cells after five years' storage at $-196^{\circ}$ C. (Table I) confirms that this technique is capable of preserving red cells intact for long periods. The increase in recovery at one year was due to the use of $1 \%$ (rather than isotonic) saline for thawing; thereafter the proportion of cells recovered intact appears to drop by approximately $1 \%$ per annum.

Earlier work had suggested that the antigenic strength of frozen red cells would show little deterioration during storage. The panel of cells reported in this paper retained their antigenic strength after three years in liquid nitrogen (Huntsman et al., 1964). Strumia et al. (1962) showed that a small panel of cells grouped satisfactorily after five months at $-93^{\circ} \mathrm{C}$. One specimen after three years' storage was equivalent to fresh cells. Bronson and McGinniss (1962) reported good preservation of antigenic properties after the storage of two samples for six months in liquid nitrogen. Gibbs et al. (1962) showed that the antigens of the $A B O$ systems were preserved after two and a half years in liquid nitrogen.

As previously observed (Huntsman et al., 1964) saline suspensions of thawed cells showed progressive lysis during further storage over a period of hours or days at $4^{\circ} \mathrm{C}$., but this feature was no more pronounced in the five-year specimens than in those frozen for a shorter period. All cell samples after repeated washing in isotonic saline showed no further haemolysis before grouping tests, some of which were carried out as long as 48 hours after thawing.

The quality of the antigen strength of red cells after five years of frozen storage is reflected by the titration scores shown in Table III, and, with few exceptions of doubtful significance, the results are similar to those obtained with the original fresh material. After this period of trial it is fair to say that cells stored by the method described compare favourably with cells frozen in high concentrations of glycerol and stored under the best conditions at $-80^{\circ} \mathrm{C}$. or below. Storage of glycerolized cells at $-20^{\circ} \mathrm{C}$. gives inferior results, and indeed few of the cells would be expected to survive for five years under such conditions.

In order to detect enzyme deterioration in the stored red cells we have previously relied on assays repeated sequentially over a number of years. As a result of such tests it appeared that the concentrations of two of the four enzymes (aldolase and aspartate aminotransferase) had fallen during storage for two years. However, it is difficult to stabilize enzyme assay systems so as to yield strictly comparable results over long periods of time, and adequate preparations for quality control of these assay procedures do not exist. The possibility was therefore considered that the observations might be due to technical variation rather than to changes in the stored enzymes (Huntsman et al., 1965). Samples after five years' storage were com- 
pared with freshly drawn specimens from the original donors, related samples being assayed simultaneously in each case. During the period of storage whenever specimens were temporarily removed from the liquid nitrogen refrigerator care was taken that the frozen blood remained at liquid nitrogen temperature. This was achieved by ensuring that the boxes containing the blood were filled with liquid nitrogen the moment they were removed from the refrigerator. The results of these tests are given in Table IV. The present evidence, though inconclusive, suggests a reasonable degree of stability of these four enzymes during storage at $-196^{\circ} \mathrm{C}$.

\section{Summary}

Tests after five years' storage of human blood in liquid nitrogen $\left(-196^{\circ}\right.$ C.) after rapid freezing shows the method to be very suitable for preservation of cells for blood group

TABLE III.-Titration Scores of Blood Group Antigens Before and Immediately After Freezing and After Storage for Various Periods. Control Values Expressed in Parentheses

\begin{tabular}{|c|c|c|c|c|c|c|c|c|c|}
\hline \multirow{2}{*}{\multicolumn{2}{|c|}{$\begin{array}{l}\text { Antigen } \\
\text { Tested and } \\
\text { Control () }\end{array}$}} & \multicolumn{6}{|c|}{ Specimen 1} & & \\
\hline & & $H(0)$ & $\mathrm{D}\left(\mathbf{R}_{\mathbf{2}} \mathrm{r}\right)$ & $E\left(R_{2} r\right)$ & $M(M N)$ & $N(M N)$ & $\mathbf{P}_{1}\left(\mathbf{P}_{1}+++\right)$ & & \\
\hline 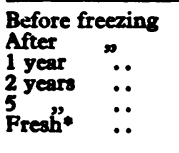 & 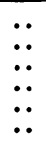 & $\begin{array}{l}26(31) \\
24(31) \\
26(32) \\
32(34) \\
31(32) \\
34\end{array}$ & $\begin{array}{l}75(82) \\
70(82) \\
84(84) \\
82(84) \\
67(82) \\
82\end{array}$ & $\begin{array}{l}57(57) \\
57(57) \\
60(62) \\
57(60) \\
52(60) \\
55\end{array}$ & $\begin{array}{l}57(57) \\
57(57) \\
55(52) \\
58(55) \\
50(52) \\
58\end{array}$ & $\begin{array}{l}31(33) \\
29(33) \\
21(23) \\
26(26) \\
26(33) \\
34\end{array}$ & $\begin{array}{l}24(34) \\
19(34) \\
16(27) \\
14(22) \\
11(22) \\
14\end{array}$ & & - \\
\hline \multirow{2}{*}{\multicolumn{2}{|c|}{$\begin{array}{l}\text { Antigen } \\
\text { Tested and } \\
\text { Control () }\end{array}$}} & \multicolumn{8}{|c|}{ Specimen 2} \\
\hline & & $\mathbf{H}(\mathbf{O})$ & $C\left(R_{1} r\right)$ & $\mathbf{D}\left(\mathbf{R}_{\mathbf{1}} \mathbf{r}\right)$ & $\mathbf{M}(\mathbf{M M})$ & $F_{y}{ }^{*} \mathbf{A}(\mathbf{F y}(\mathrm{a}+))$ & & & \\
\hline 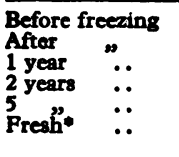 & 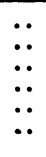 & $\begin{array}{l}31(31) \\
26(31) \\
29(32) \\
34(34) \\
31(32) \\
33\end{array}$ & $\begin{array}{l}40(40) \\
40(40) \\
42(52) \\
55(55) \\
27(37) \\
37\end{array}$ & $\begin{array}{l}74(75) \\
69(75) \\
74(75) \\
80(80) \\
65(75) \\
77\end{array}$ & $\begin{array}{l}67(67) \\
64(67) \\
57(57) \\
58(57) \\
54(58) \\
58\end{array}$ & $\begin{array}{l}72(74) \\
72(74) \\
56(56) \\
61(59) \\
71(76) \\
76\end{array}$ & & & \\
\hline \multirow{2}{*}{\multicolumn{2}{|c|}{$\begin{array}{l}\text { Antigen } \\
\text { Tested and } \\
\text { Control () }\end{array}$}} & \multicolumn{8}{|c|}{ Specimen 3} \\
\hline & & $A(A)$ & $C\left(R_{1} r\right)$ & $D\left(R_{1} r\right)$ & $\mathbf{N}(\mathrm{NN})$ & $\mathrm{Lu}^{\mathrm{a}}(\mathrm{Lu}(\mathrm{a}+))$ & $F^{2} \mathbf{A}(F y(a+))$ & & \\
\hline 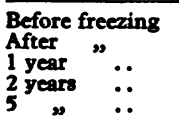 & $\begin{array}{l}\because \\
\because \\
\because \\
\therefore\end{array}$ & $\begin{array}{l}61(61) \\
49(61) \\
54(58) \\
51(56) \\
51(75)\end{array}$ & $\begin{array}{l}44(47) \\
42(47) \\
44(52) \\
45(55) \\
27(37)\end{array}$ & $\begin{array}{l}75(75) \\
74(75) \\
74(75) \\
74(80) \\
75(75)\end{array}$ & $\begin{array}{l}35(35) \\
35(35) \\
31(31) \\
33(33) \\
34(40)\end{array}$ & $\begin{array}{l}27(38) \\
22(38) \\
27(30) \\
26(24) \\
20(27)\end{array}$ & $\begin{array}{l}69(71) \\
66(71) \\
64(56) \\
59(59) \\
71(76)\end{array}$ & & \\
\hline \multirow{2}{*}{\multicolumn{2}{|c|}{$\begin{array}{l}\text { Antigen } \\
\text { Tested and } \\
\text { Contrul () }\end{array}$}} & \multicolumn{5}{|c|}{ Specimen 4} & & & \\
\hline & & $\mathbf{H}(\mathbf{O})$ & $\mathrm{D}\left(\mathrm{R}_{\mathbf{2}} \mathrm{r}\right)$ & $E\left(R_{d} \mathbf{r}\right)$ & $M(M M)$ & $\mathbf{P}_{1}\left(\mathbf{P}_{1}+++\right)$ & & & \\
\hline 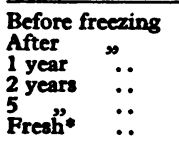 & 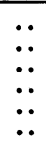 & $\begin{array}{l}26(31) \\
24(31) \\
24(32) \\
28(34) \\
26(32) \\
32\end{array}$ & $\begin{array}{l}74(72) \\
72(72) \\
82(84) \\
82(84) \\
75(82) \\
82\end{array}$ & $\begin{array}{l}56(52) \\
56(52) \\
56(62) \\
57(60) \\
52(60) \\
57\end{array}$ & $\begin{array}{l}57(57) \\
55(57) \\
57(57) \\
57(57) \\
52(58) \\
60\end{array}$ & $\begin{array}{l}29(22) \\
21(22) \\
26(27) \\
22(22) \\
16(22) \\
24\end{array}$ & & & \\
\hline \multirow{2}{*}{\multicolumn{2}{|c|}{$\begin{array}{l}\text { Antigen } \\
\text { Tested and } \\
\text { control () }\end{array}$}} & \multicolumn{8}{|c|}{ Specimen 5} \\
\hline & & $\mathbf{H}(\mathbf{O})$ & $C\left(R_{1}^{\mathbb{W}} r\right)$ & $C^{w}\left(R_{1}^{\omega} r\right)$ & $D\left(R_{1}^{\pi} r\right)$ & $\mathbf{M}(\mathbf{M M})$ & $P_{1}\left(P_{1}+++\right)$ & Kell $\mathbf{\Delta}(\mathbf{K}+)$ & $F y^{*} \Delta(F y(a+))$ \\
\hline 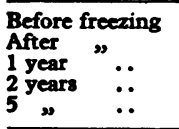 & 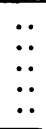 & $\begin{array}{l}31(31) \\
31(31) \\
31(32) \\
32(34) \\
34(32) \\
\end{array}$ & $\begin{array}{l}40(45) \\
35(45) \\
35(52) \\
35(35) \\
20(37)\end{array}$ & $\begin{array}{l}75(75) \\
72(75) \\
77(77) \\
77(75) \\
63(75)\end{array}$ & $\begin{array}{l}77(84) \\
77(84) \\
74(75) \\
78(80) \\
65(75) \\
\end{array}$ & $\begin{array}{r}58(60) \\
57(60) \\
53(57) \\
57(57) \\
54(58) \\
\end{array}$ & $\begin{array}{l}31(21) \\
31(21) \\
27(27) \\
24(22) \\
24(22) \\
\end{array}$ & $\begin{array}{l}61(64) \\
61(64) \\
62(60) \\
66(66) \\
81(76) \\
\end{array}$ & $\begin{array}{l}66(66) \\
63(66) \\
60(56) \\
61(59) \\
71(76) \\
\end{array}$ \\
\hline \multirow{2}{*}{\multicolumn{2}{|c|}{$\begin{array}{l}\text { Antigen } \\
\text { Tested and } \\
\text { Control () }\end{array}$}} & \multicolumn{8}{|c|}{ Specimen 6} \\
\hline & & $\mathbf{H}(\mathbf{0})$ & $\mathrm{D}\left(\mathbf{R}_{2}^{\mathrm{T}} \mathbf{r}\right)$ & $D \square\left(R_{2}^{\mathfrak{v}} r\right)$ & $E\left(R_{2}^{V} r\right)$ & $\mathbf{M}(\mathrm{MN})$ & $\mathbf{N}(\mathrm{MN})$ & $\mathbf{P}_{1}\left(\mathbf{P}_{1}+\right)$ & $F y^{*} \Delta(F y(a+))$ \\
\hline $\begin{array}{l}\text { Before freezing } \\
\text { After } \quad " \\
1 \text { year } \\
2 \text { years } \\
5\end{array}$ & $\begin{array}{l}\because \\
\because \\
\because\end{array}$ & $\begin{array}{l}26(31) \\
24(31) \\
21(32) \\
24(34) \\
26(32) \\
\end{array}$ & $\begin{array}{l}17(17) \\
14(17) \\
4(9) \\
12(35+) \\
8(0+)\end{array}$ & $\begin{array}{l}52(46) \\
47(46) \\
50(45) \\
49(66+) \\
66(66+)\end{array}$ & $\begin{array}{l}57(57) \\
52(57) \\
57(62) \\
60(60) \\
57(60) \\
\end{array}$ & $\begin{array}{l}57(57) \\
50(57) \\
55(52) \\
55(55) \\
52(52) \\
\end{array}$ & $\begin{array}{l}21(28) \\
19(28) \\
23(23) \\
24(26) \\
26(33) \\
\end{array}$ & $\begin{array}{r}14(11) \\
8(11) \\
4(11) \\
4(11) \\
4(4) \\
\end{array}$ & $\begin{array}{l}66(66) \\
63(66) \\
59(56) \\
61(59) \\
71(76) \\
\end{array}$ \\
\hline \multirow{2}{*}{\multicolumn{2}{|c|}{$\begin{array}{l}\text { Antigen } \\
\text { Tested and } \\
\text { Control () }\end{array}$}} & \multicolumn{3}{|c|}{ Specimen 7} & & & & & \\
\hline & & $\mathbf{H}(\mathbf{O})$ & $c(r r)$ & $\mathbf{N}(\mathbf{N N})$ & & & & & \\
\hline $\begin{array}{l}\text { Before freezing } \\
1 \text { year } \\
2 \text { years } \quad \ldots \\
5 \text { Fresh } \\
\text { Fr }\end{array}$ & 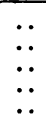 & $\begin{array}{l}29(32) \\
31(32) \\
26(34) \\
31(32) \\
32\end{array}$ & $\begin{array}{l}76(77) \\
62(65) \\
75(75) \\
57(67) \\
67\end{array}$ & $\begin{array}{l}33(36) \\
31(31) \\
33(33) \\
26(40) \\
33\end{array}$ & & & & & \\
\hline
\end{tabular}

All tests saline titrations except $\Delta=$ Antiglobulin (Coombs) test and $\sigma=$ antiglobulin test with incomplete Anti-D. Different control (cells from different donor) $=+$ * Fresh blood taken from original donors tested in parallel with five-year stored sample.

TABLE IV.-Comparison of the Enzyme Content of Red Cells Stored for Five Years with those of Fresh Cells from the same Donors

\begin{tabular}{|c|c|c|c|c|c|c|c|c|}
\hline \multirow{2}{*}{ Specimen } & \multicolumn{2}{|c|}{ Aldolase* } & \multicolumn{2}{|c|}{ Aspartate Aminotransferase* } & \multicolumn{2}{|c|}{ Glucose 6-Phosphate Dehydrogenaset } & \multicolumn{2}{|c|}{ 6-Phosphogluconate Dehydrogenaset } \\
\hline & Fresh & Stored & Fresh & Stored & Fresh & Stored & Fresh & Stored \\
\hline $\begin{array}{l}1 \\
2 \\
4 \\
7\end{array}$ & $\begin{array}{l}1.2 \\
1.1 \\
1.4 \\
1.3\end{array}$ & $\begin{array}{l}1.1(92 \%) \\
0.9(82 \%) \\
0.8(57 \%) \\
1.5(115 \%)\end{array}$ & $\begin{array}{l}0.5 \\
0.5 \\
0.7 \\
0.6\end{array}$ & $\begin{array}{l}0.6(120 \%) \\
0.5(100 \%) \\
0.6(86 \%) \\
0.7(117 \%)\end{array}$ & $\begin{array}{l}3.3 \\
3.7 \\
4.5 \\
4.5\end{array}$ & $\begin{array}{l}2.3(70 \%) \\
3.5(95 \%) \\
1.7(38 \%) \\
5.6(125 \%)\end{array}$ & $\begin{array}{l}4 \cdot 1 \\
4 \cdot 5 \\
4 \cdot 2 \\
4 \cdot 5\end{array}$ & $\begin{array}{l}2 \cdot 3(56 \%) \\
2 \cdot 8(62 \%) \\
2 \cdot 1(50 \%) \\
3 \cdot 9(85 \%)\end{array}$ \\
\hline
\end{tabular}


reference work. It is probably the method of choice for rare blood samples.

Intraerythrocytic enzymes appear to be reasonably stable under the conditions of storage.

\section{REFERENCES}

Bronson, W. R., and McGinniss, M. H. (1962). Blood, 20, 478. Doebbler, G. F., Buchheit, R. G., and Cowley, C. W. (1965). Cryobiology, 2,8 .
Gibbs, M. B., McCord, E. B., Collins, W. S., Schrider, C. T., and Akeroyd, J. H. (1962). Transfusion (Philad.), 2, 100.

Huntsman R G Hurn B. A. L. Ikin E. W., Lehmann, H., and Liddell, J. (1962). Brit. med. ऊ., 2, 1508.

Liddell, J. (1962). Brit. Med. (1964)." Transfusion (Philad.), 4, 354.

- (1965). In Proceedings of 10th Congress of International Society of Blood Transfusion, Stockholm, 1964 edited by L. Holländer, p. 709 . Basel.

Strumia, M. M., Colwell, L. S., and Strumia, P. V. (1960). F. Lab. clin. Med., 56, 587.

Strumia, P. V., Strumia, M. M., Colwell, L. S., and Toorg, B. (1962) Transfusion (Philad.), 2, 31 .

\title{
Haemorrhagic Necrosis of the Intestine
}

\author{
J. S. MCKINNELL,* M.B., CH.B., D.PATH., F.C.PATH. ; M. S. KEARNEY, † M.B., CH.B.
}

The fact that necrosis of the bowel can occur in the absence of demonstrable occlusion of the mesenteric vessels has long been recognized. Kleckner, Bargen, and Baggenstoss (1953) recognized that enterocolitis occurred in heart disease, but Wilson and Qualheim (1954) seem to have been the first to define a specific syndrome occurring mainly in elderly subjects suffering from heart disease and characterized by patchy haemorrhagic necrosis of the intestinal mucosa unrelated to the distribution of the mesenteric arteries. These authors observed eight cases of acute haemorrhagic enterocolitis in one and a half years and discovered 12 similar cases in a survey of the hospital necropsy records between 1947 and 1953. Subsequently a number of American authors have described further cases of the same type: Ming and Levitan (1960) encountered 11 in three years among 698 necropsies; Glotzer and Shaw (1959) collected nine in a period of 10 years ; Grosh, Mann, and O'Donnell (1965) described 10 cases seen in three years; in a study of hospital records over a 12-year period Berger and Byrne (1961) found 23 cases of massive bowel infarction in the absence of mesenteric artery or vein occlusion, though at necropsy the majority showed infarction in the distribution of the superior mesenteric artery and only a minority showed involvement of multiple segments at random sites ; Fogarty and Fletcher (1966) studied 18 patients during five years; Drucker, Davis, Holden, and Reagan (1964) observed seven patients within two years. The last-mentioned authors discuss the pathogenesis. In a report from Australia, McGovern and Goulston (1965) recorded 33 cases in a 14-year period.

No series of exactly comparable cases seems to have been reported from this country. During the five months July to November 1964 we encountered 13 cases among fewer than 200 necropsies. Previous to this period such cases were very rare in the experience of one of us (J. S. McK.), and subsequently in the same hospital there have been only two similar cases among over 1,000 necropsies. The only unusual feature of the five months in question was that they were unusually dry ; the rainfall in these five months totalled 3.5 in. $(8.9 \mathrm{~cm}$.), as compared with an average of 7 in. $(17: 8 \mathrm{~cm}$.) for the same five months in the years 1947 to 1961 . No other late summer and autumn since 1947 had been so dry.

Reports of two representative cases are given.

\section{Case $\cdot 1$}

The patient, a man aged 85 , was admitted to hospital with a history of abdominal pain for some days, becoming more severe in the previous 24 hours.

* Consultant Pathologist, Selly Oak Hospital, Birmingham 29.

+ Surgeon Lieutenant, R.N. ; late Reqistrar in Pathology, Selly Oak Hospital, Birmingham 29.
On examination the transverse colon was distended and showed visible peristalsis. He was dehydrated. The rectum contained hard faeces. Levels of serum electrolytes were: sodium $134 \mathrm{mEq} / \mathrm{l}$, potassium $3.5 \mathrm{mEq} / 1$., chloride $86 \mathrm{mEq} / 1$., and bicarbonate 29 $\mathrm{mEq} / \mathrm{l}$. The blood urea was $76 \mathrm{mg} . / 100 \mathrm{ml}$. A provisional diagnosis of carcinoma of the colon was made. One litre of dextrose saline and one litre of Dacron's solution were infused in 12 hours, but the patient collapsed unexpectedly and died 48 hours after admission.

At necropsy the heart was of normal size. The myocardium was flabby. The valves were normal. The coronary arteries were moderately dilated and there was diffuse thickening of their walls, but there were no atheromatous plaques and no restriction of their lumina. The lungs were oedematous and congested. The liver was rather small and its surface was mottled, due to irregular patches of congestion. The gastric mucosa and the mucosa of the whole length of the small intestine were acutely congested, and gas bubbles were observed under the mucosa of the duodenum. There were small haemorrhages in the mesentery of the jejunum. The mucosa of the caecum was severely haemorrhagic and much thickened. In the transverse colon there were two segments in which the mucosa was greenish and the wall of the bowel thinned owing to dilatation. The mucosa of the pelvic colon was thickened and haemorrhagic, like that of the caecum. The aorta was well preserved for the age of the subject, and the superior and inferior mesenteric arteries and veins were patent. The kidneys showed some loss of cortical substance with coarse granularity of the subcapsular surface, suggestive of scarring due to senile arteriosclerosis. There was moderate dilatation of both renal pelves, the bladder was moderately dilated and trabeculated, and the prostate was enlarged.

On histological examination the more severely affected areas of the small intestine, the caecum, and the pelvic colon all showed essentially similar changes, consisting of haemorrhage into the mucosa and severe congestion of the submucosa with thrombosis

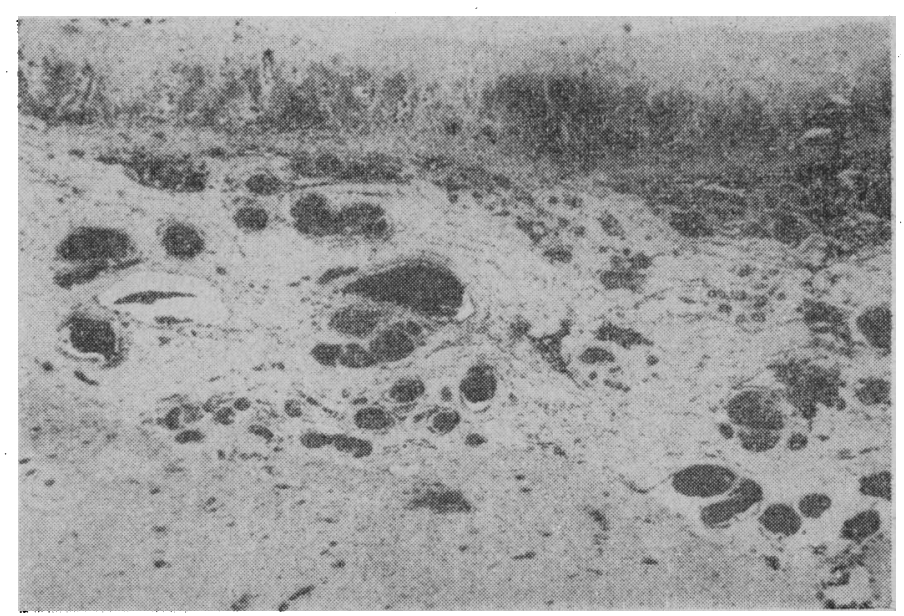

FIG. 1.-Case 1. Superficial necrosis of the mucosa with haemorrhage in the deeper zone. Severe congestion of the vessels of the submucosa with some oedema. 